\title{
MENGELOLA KONFLIK DALAM GEREJA
}

\author{
Agung Gunawan
}

\section{ABSTRAKSI}

Gereja adalah miniatur Kerajaan Allah dalam dunia yang fana ini yang didalamnya terdiri dari manusia-manusia berdosa yang telah ditebus oleh darah Kristus. Oleh sebab itu, gereja bukan sorga dan tempat berkumpulkan para malaikat yang sempurna tanpa cacat cela. Gereja merupakan kumpulan orang-orang yang terus menerus masih mengalami proses pengudusan hingga mencapai tahap yang sempurna ketika Tuhan Yesus dating kembali.

Oleh sebab itu, konflik dalam gereja bukanlah sesuatu yang aneh namun suatu kelaziman. Konflik adalah bagian dari dinamika kehidupan manusia. Meskipun demikian, konflik tidak boleh dibiarkan begitu saja, karena akan membawa dampak kepada kehancuran gereja. Konflik yang terjadi dalam gereja harus dikelola dengan baik dan tepat agar konflik dapat diatasi. Dengan demikian maka gereja akan dapat terus mengembangkan diri kearah pemenuhan terhadap panggilan kesempurnaan di dalam Kristus.

Kata Kunci: gereja, konflik, mengelola konflik.

\section{PENDAHULUAN}

Gereja merupakan kumpulan orang-orang yang dipanggil keluar dari kegelapan untuk masuk kedalam terang-Nya yang ajaib untuk memberitakan perbuatan-perbuatan Allah yang besar (I Petrus 2:9). Mengingat bahwa gereja adalah kumpulan dari orang-orang berdosa yang sedang mengalami proses pengudusan, maka di dalam proses inilah gereja tidak dapat mengelak dari konflik.

Konflik bisa terjadi karena masalah-masalah yang berkaitan dengan organisasi, seperti program gereja (organization conflicts) dan konflik juga bisa terjadi antar pribadi dalam gereja (personal conflicts). Konflik bisa terjadi antar kelompok-kelompok dalam gereja (intergroup conflicts) dan juga bisa terjadi antar anggota dalam kelompok (interpersonal conflicts). Namun disisi lain, gereja juga mmiliki tugas untuk memberitakan perbuatan- 
perbuatan Allah yang besar, maka gereja harus mampu untuk mengelola konflik secara benar agar gereja tidak mempermalukan nama Tuhan.

Mengapa konflik dapat muncul dalam gereja? Apa tanda-tanda munculnya konflik dalam gereja? Apa saja level-level konflik dalam gereja dan bagaimana kiat mengelola konflik dalam gereja? Tulisan ini akan menjawab pertanyaan-pertanyaan di atas untuk memberikan pemahaman yang jelas tentang konflik dalam gereja dengan segala macam dimensinya.

\section{DEFINISI KONFLIK}

Meskipun tidak ada definisi tunggal tentang konflik, definisi yang paling tepat adalah konflik melibatkan dua kelompok independen, dimana satu kelompok merasakan beberapa ketidakcocokan di antara mereka. Jadi konflik adalah suatu kondisi disharmoni antara dua atau lebih individu karena adanya benturan kepentingan diantara mereka. ${ }^{1}$

Di dalam konflik ada dua proses yaitu: (1) "proses di mana satu pihak merasakan bahwa kepentingannya bertentangan /ditentang oleh pihak lain", dan (2) "proses interaktif yang mana didalamnya terjadi ketidakcocokan, perselisihan, atau ketidaksetujuan di antara entitas sosial"²

\section{Penyebab Munculnya Konflik}

\section{Perbedaan Persepsi dari Data Sensori}

Setiap orang memiliki persepsi yang berbeda tentang apa yang diterima oleh panca inderanya (melihat, mendengar, meraba, merasa, dan mencium). ${ }^{3}$ Misalnya, seseorang akan memiliki persepi yang positif ketika melihat satu obyek, namun orang lain akan memiliki persepsi yang negatif ketika melihat obyek yang sama. Di dalam gereja ada sebagaian orang yang merasa nyaman dengan musik band untuk mengiringi ibadah, namun ada sebagian yang merasa kurang nyaman apabila ibadah diiringi dengan musik band. Dari uraian di atas, kita dapat melihat bahwa perbedaanperbedaan persepsi terhadap apa yang diterima oleh mata dan telinga dapat menimbulkan konflik di antara anggota gereja.

\section{Pertentangan Keyakinan}

Setiap individu memiliki keyakinan yang berbeda-beda. Ketika keyakinan yang dimiliki oleh individu-individu dalam gereja saling bertentangan, maka konflik tidak dapat terelakkan. ${ }^{4}$ Misalnya, di dalam 
diukur secara kuantitas yaitu dengan jumlah anggota yang banyak, namun hamba Tuhan memiliki keyakinan bahwa gereja yang bertumbuh harus diukur secara kualitas yaitu kedewasaan rohani jemaat bukan kuantitas. Pertentangan keyakinan antara majelis dan hamba Tuhan dalam gereja sering memicu munculnya konflik dalam gereja.

\section{Perasaan Yang Terganggu}

Seringkali konflik dalam gereja juga muncul karena adanya perasaan yang terganggu disebabkan oleh ucapan-ucapan yang menyinggung perasaan sesama anggota dalam gereja. ${ }^{5}$ Perasaan yang tersinggung seringkali menyangkut harga diri seseorang. Di dalam gereja yang terdiri dari bermacam-macam temperamen dan karakter seringkali perkataan, perilaku dan sikap seseorang dapat memicu terjadinya konflik.

\section{Persaingan Keinginan}

Setiap individu dalam gereja memiliki keinginan untuk memajukan pekerjaan Tuhan, namun seringkali seseorang memaksa kehendak agar keinginannnya dituruti. ${ }^{6}$ Ketika keinginannya tidak dituruti dan keinginan orang lain yang dituruti, maka dapat dipastikan bahwa konflik akan terjadi karena adanya persaingan keinginan di antara anggota dalam gereja.

Seseorang yang tidak diterima keinginannya akan merasa diabaikan dan tidak dihargai. Akibatnya ia akan membuat masalah yang akan memicu konflik dalam komunitas gereja.

\section{Tanda-Tanda Munculnya Konflik}

Ketika di dalam gereja terjadi konflik yang berkepanjangan dan tidak segera dikelola secara baik dan sehat, maka akan terjadi dampak yang negatif bagi gereja, antara lain:

\section{Jemaat dan Persembahan Berkurang}

Gereja yang memiliki konflik di dalamnya akan membawa dampak yang dapat dilihat secara kasat mata yaitu berkurangnya jumlah anggota dari gereja tersebut. ${ }^{7}$ Hal itu dapat dilihat dari grafik kehadiran jemaat yang terus menunjukkan penurunan secara signifikan. Mengapa hal ini dapat terjadi? Hal ini disebakan karena jemaat tidak merasa nyaman berada dalam lingkungan gereja yang tidak kondusif. Jemaat datang kegereja untuk mencari kedamaian dan ketenangan. 
Apabila gereja penuh dengan konflik, maka jemaat akan merasa tidak nyaman dan tidak ada damai. Akibatnya jemaat akan meninggalkan gereja tersebut dan pindah mencari gereja lain yang didalamnya ada kedamaian. Ketika anggota jemaat yang hadir berkurang, maka sebagai konsekwensi logisnya uang persembahan juga berkurang secara drastis. Akibatnya maka gereja akan mengalami kesulitan untuk membiayai kebutuhan finansial gereja karena gereja mengalami defisit keuangan.

\section{Partisipasi Jemaat Menurun}

Apabila gereja penuh dengan konflik, maka hal itu akan membawa dampak pada penurunan dari partisipasi jemaat dalam aktifitas pelayanan gereja. ${ }^{8}$ Banyak anggota gereja sebenarnya menyadari panggilan untuk terlibat dalam pekerjaan Tuhan. Banyak anggota jemaat yang memiliki kerinduan untuk melayani Tuhan. Namun tatkala mereka melihat bahwa di dalam gereja banyak konflik, maka mereka menjadi enggan dan akhirnya menarik diri dari pelayanan.

Fakta menunjukkan bahwa banyak gereja-gereja yang sulit untuk mencari orang-orang yang mau terlibat dalam pelayanan seperti menjadi majelis, pengurus komisi, dan guru sekolah minggu. Akibatnya maka yang terlibat dalam pelayanan hanya orang-orang yang sama dan tidak ada tenaga baru. Selain daripada itu, banyak orang-orang yang memiliki tugas yang merangkap-rangkap, sehingga menyebabkan pelayanan menjadi tidak efektif dan tidak berkembang dengan baik dan maksimal.

\section{Perubahan Perilaku Hamba Tuhan}

Hal lain yang juga harus diperhatikan adalah konflik dalam gereja akan membawa dampak terhadap perilaku hamba Tuhan yang melayani di gereja tersebut. ${ }^{9}$ Karena hamba Tuhan merupakan tokoh sentral di dalam gereja, maka ia adalah pribadi yang sangat terkena imbasnya secara hebat ketika gereja mengalami konflik.

Perubahan yang terjadi pada diri hamba Tuhan diantaranya adalah:

- Hamba Tuhan mulai malas melakukan visitasi jemaat

- Hamba Tuhan mulai acuh tak acuh dalam pelayananannya

- Kotbahnya tidak dipersiapkan dengan baik

- Hamba Tuhan menjadi pasif dalam rapat

- Hamba Tuhan kurang memperhatikan keluarganya

- Hamba Tuhan lebih mementingkan hobinya seperti memancing daripada memikirkan pekerjaan Tuhan 


\section{Munculnya Keluhan-Keluhan}

Ketika gereja berada dalam situasi konflik, maka pelayanan gereja terhadap jemaatnya akan tidak berjalan secara maksimal. ${ }^{10}$ Hamba Tuhan dan majelis yang terlibat konflik pasti tidak akan dapat melakukan tugas dan tanggungjawabnya dengan baik. Bahkan mereka cenderung akan mengabaikan tugas dan kewajibannya.

Hal itu akan dapat dirasakan oleh anggota jemaat yang membutuhkan pelayanan yang baik dan benar. Akibatnya banyak anggota jemaat yang menyampaikan keluhan-keluhan, baik terhadap pelayanan dari hamba Tuhan mapun dari majelis atau pengurus gereja yang bertanggungjawab atas jalannya pelayanan dalam gereja. Banyak anggota jemaat yang merasa tidak puas terhadap apa yang dilakukan oleh orang-orang yang terlibat dalam pelayanannya.

Tidak jarang anggota gereja yang melakukan kritik yang keras, baik melalui lisan maupun surat. Bahkan tidak jarang juga muncul surat-surat kaleng yang mendeskridikkan hamba Tuhan maupun para aktifis gereja. Apabila hal ini dibiarkan, maka banyak jemaat yang akan keluar bahkan bukan tidak mungkin gereja akan mengalami perpecahan.

\section{Jenis-Jenis Konflik}

Ada dua macam konflik yang terjadi dalam kehidupan gereja yaitu:

\section{Konflik Substantif Dan Konflik Afektif ${ }^{11}$}

Konflik Substantif adalah konflik yang melibatkan perbedaan pendapat di antara anggota kelompok tentang isi dari tugas-tugas yang dilakukan atau kinerja itu sendiri. Konflik jenis ini terjadi ketika dua atau lebih entitas sosial tidak setuju pada pengakuan dan solusi untuk masalah tugas, termasuk perbedaan dalam sudut pandang, gagasan, dan pendapat.

Konflik Afektif adalah konflik yang berkaitan dengan hubungan interpersonal atau ketidak cocokan antar pribadi dan tidak terkait langsung dengan pencapaian fungsi kelompok.Baik konflik substantif dan afektif memiliki dampak yang negatif berhubungan dengan kepuasan anggota tim dan kinerja tim dalam pelayan digereja.

\section{Konflik Organisasi Dan Interpersonal ${ }^{12}$}

Konflik organisasi, apakah itu substantif atau afektif, dapat dibagi menjadi interorganisasi dan intraorganisasi. Konflik interorganisasi terjadi 
antara dua atau lebih organisasi yang berbeda, sedangkan konflik intraorganisasi adalah konflik yang ada di dalam organisasi, misalnya konflik yang terjadi antar komisi yang ada dalam gereja. Konflik interpersonal mengacu pada konflik antara dua atau lebih individu (tidak mewakili kelompok mereka). Konflik interpersonal dibagi menjadi intragrup dan intergrup. Konflik intragrup terjadi antara anggota dalam kelompok yang sama, sedangkan konflik intergrup terjadi antara pribadi-pribadi dari kelompok-kelompok yang berbeda.

\section{Level-Level Konflik}

\section{Problem To Solve}

Dalam level pertama ini, orang-orang yang terlibat konflik menyadari bahwa mereka memiliki konflik yang harus segera diselesaikan. ${ }^{13}$ Dalam level ini, pihak-pihak yang terlibat konflik fokus pada penyelesaian masalah (problem oriented), bukan fokus pada pribadi yang terlibat konflik (person oriented).

Pada level ini, tidak ada penyerang kepada pribadi baik secara verbal maupun non verbal. Dalam level ini, keduanya akan berusaha sekuat tenaga untuk segera mencari cara untuk menyelesaikan konflik yang terjadi. Kedua belah pihak memiliki sikap yang optimis bahwa masalah yang mereka hadapi dapat diselesaikan dengan baik.

\section{Disagreement}

Level Il dari konflik ini kondisinya lebih sulit dibandingkan dengan level pertama, karena disini terjadi ketidaksepahaman antara pribadi-pribadi yang terlibat konflik. ${ }^{14}$ Berbeda dengan level pertama, pada level ini fokus bukan kepada penyelesaian masalah (problem solving), tapi cenderung untuk melindungi diri (self protection).

Pada level ini, pihak-pihak yang konflik berusaha untuk mencari keselamatan atas diri masing-masing. Mereka yang terlibat konflik tidak mau secara terbuka menyatakan bahwa mereka memiliki masalah. Mereka hanya menyampaikan hal-hal yang bersifat umum, walaupun sebenarnya mereka memiliki masalah-masalah yang spesifik. Akibatnya masalah yang terjadi akan sulit diselesaikan, sehingga konflik akan terus mengambang tanpa ada akhirnya (floating).

\section{Contest}

Dalam level III ini, kedua pihak yang terlibat konflik berpindah dari 
upaya melindungi diri masing-masing kepada upaya untuk menjadi pihak yang menang yang mengalahkan lawannya ( win/lose). ${ }^{15}$

Pada level ini, pihak-pihak yang berkonflik masing-masing memaksakan kehendaknya kepada lawannya. Akibatnya akan sulit untuk menemukan solusi untuk menyelesaikan konflik yang terjadi. Apabila kondisi ini dibiarkan, maka akibatnya konflik makin hari semakin meruncing dan akan membawa kepada level yang berikutnya yaitu fight/flight.

IV. Fight/Flight Level ini merupakan kelanjutan dari level III. Dalam level ini pihak-pihak yang terlibat konflik bukan hanya ingin menang atas lawannya, tapi juga ingin melukai atau menyingkirkan lawannya. ${ }^{16}$ Pada level ini, pihak-pihak yang terlibat konflik sudah tidak percaya bahwa lawannya mau dan dapat berubah, karena dirinya sendiri tidak mau dan dapat berubah. Sehingga satu-satunya jalan adalah menyingkirkan orang tersebut dari organisasi gereja bahkan kalau bisa juga menyingkir dari gereja.

Level ini biasanya akan berujung kepada salah satu pihak keluar atau menyingkir dari gereja dengan membawa pengikutnya. Dengan demikian maka perpecahan gereja tidak dapat dielakkan.

\section{Intractable Situations}

Level ini adalah level yang tidak dapat dikelola, dimana konflik sudah tidak dapat lagi terkontrol oleh pihak-pihak yang terlibat. ${ }^{17}$ Level ini merupakan kelanjutan dari level IV yang memiliki orientasi untuk menyingkirkan lawannya. Namun level ini lebih daripada level IV karena pihak-pihak yang terlibat konflik berupaya untuk menghancurkan lawannya dengan melakukan tindakan kekerasan, baik secara verbal maupun non verbal. Apabila lawannya belum hancur maka ia tidak akan mengalami kepuasan. Apabila hal ini terjadi, maka konflik yang terjadi antar anggota gereja akan berujung kepada masalah hukum.

Gereja harus menghindari konflik yang terjadi tidak mencapai level V karena akibatnya gereja akan menjadi tontonan dan dipermalukan oleh orang-orang di luar gereja. Dengan demikian nama Tuhan bukan dipermuliakan, namun sebaliknya akan dipermalukan. Oleh sebab itu, konflik yang terjadi harus segera dikelola secara baik dan benar. Bagaimana kiat mengelola konflik yang baik dan benar? 


\section{Kiat Mengelola Konflik}

\section{Menyelesaikan Masalah (Resolve The Problem)}

Di dalam mengelola konflik secara baik dan benar, maka pertamatama kita perlu fokus kepada masalah yang ada. ${ }^{18}$ Disini kita mengindentifikasi tentang akar penyebab munculnya masalah, siapa saja orang-orang yang terlibat, serta mencari langkah yang tepat untuk menyelesaikan masalah tersebut.

Masalah yang muncul harus diselesaikan secara tuntas sampai keakarnya bukan hanya permukaannya saja. Untuk itu maka perlu ada komitmen dari pihak-pihak yang terlibat konflik untuk mau membuka diri dan menyatakan secara terbuka apa yang dialami, dirasakan, dipikirkan, diinginkan, serta apa yang diharapkan akan terjadi ketika masalahnya diselesaikan. Dengan demikian, maka masing-masing pihak tahu apa yang menyebabkan masalah terjadi dan hal ini akan memudahkan untuk menyelesaikan masalah secara tuntas.

\section{Memperbaiki Hubungan (Restore The Relationship)}

Setelah masalah yang ada dapat diselesaikan secara tuntas, maka berikutnya yang perlu dilakukan adalah memperbaiki hubungan antara pihak-pihak yang terlibat konflik. ${ }^{19}$ Konflik pasti menimbulkan luka batin, kemarahan, kebencian dan dendam bagi orang-orang yang terlibat konflik. Dengan kata lain karena konflik hubungan mereka menjadi rusak.

Meskipun masalah yang menjadi pemicu terjadinya konflik sudah diselesaikan, namun hubungan di antara mereka yang terlibat konflik tidak secara otomatis juga akan menjadi baik. Hubungan mereka masih ada ketidaknyamanan. Untuk itu, hubungan di antara orang-orang yang terlibat konflik harus dipulihkan agar hubungan mereka menjadi seperti sebelum terjadi konflik. Dengan demikian maka konflik akan terselesaikan secara tuntas.

\section{Mengubah Sistem (Rebuilt The Sistem)}

Setelah masalah diselesaikan secara tuntas dan hubungan sudah dipulihkan, maka langkah berikutnya adalah mengubah sistem yang ada. ${ }^{20}$ Sistem seringkali memiliki andil yang besar dalam terciptanya konflik. Sistem disini bisa berupa kondisi, peraturan, serta organisasi dalam gereja yang menyebabkan terjadinya konflik. 
Apabila sistem tidak diubah maka konflik akan dapat muncul kembali. Oleh sebab itu, pada bagian ini perlu dikaji dengan cermat sistem yang memiliki andil terjadinya sebuah konflik. Setelah diketahui, maka orangorang yang terlibat konflik perlu bersama-sama mengubah sistem yang ada, sehingga tidakAkan terjadi lagi konflik yang sama.

\section{PENUTUP}

Konflik dalam gereja tidak dapat dan tidak boleh dihindari. Konflik selalu ada dalam seluruh dimensi kehidupan manusia, termasuk dalam kehidupan gereja. Gereja harus belajar untuk dapat mengelola konflik dengan cantik dn cerdas. Agar gereja tidak berjalan di dalam konflik tapi gereja berjalan di atas konflik. Gereja tidak dikuasai konflik, tapi gereja yang menguasai konflik. Ini adalah hasil dari pengelolaan konflik gereja secara tepat dan benar.

\section{DAFTAR RUJUKAN}

Alper, S., Tjosvold, D., \& Law, K. S. (2000). Conflict Management, Efficacy, and Performance In Organizational Teams. Personnel Psychology, $53,625-642$.

Leas, Speed B. (1998). Moving Your Church Through Conflict. The Alban Institut.

Miller, Sherod (1993). Talking and Listening Together Interpersonal communication Programs, Inc..

Rahim, M., Antonioni, D., \& Psenicka, C. (2001). A Structural Equations Model of Leader Power, Subordinates' Styles of Handling Conflict, And Job Performance. International Journal of Conflict Management, 12(3), 191.

Wall, J. A., Jr., \& Callister, R. R. (1995). Conflict and Its Management. Journal of Management, 21, 515-558.

\section{EndNote}

1. Wall, J. A., Jr., \& Callister, R. R. (1995). Conflict and Its Management. Journal of Management, 21, p.517

2. Rahim, M. A. (1992). Managing conflict in organizations (2nd ed.). Westport, CT: Praeger. p.16

3. Miller, Sherod (1993). Talking and Listening Together Interpersonal communication Programs, Inc.

4. Ibid.

5. Ibid.

6. Ibid.

7. Leas, Speed B. (1998). Moving Your Church Through Conflict. The Alban Institut. 
8. Ibid.

9. Ibid.

10. Ibid.

11. Rahim, M., Antonioni, D., \& Psenicka, C. (2001). A Structureal Equations Model of Leader Power, Subordinates' Styles of Handling Conflict, And Job Performance. International Journal of Conflict Management, 12(3), 191.

12. Ibid.

13. Leas, 1998.

14. Ibid.

15. Ibid.

16. Ibid.

17. Ibid.

18. Miller, 1993

19. Ibid.

20. Ibid. 